\title{
Upregulation of intrarenal angiotensinogen in diabetes
}

\author{
Dulce Elena Casarini \\ Hypertension Research (2010) 33, 1106-1107; doi:10.1038/hr.2010.163; published online 23 September 2010
}

$\mathrm{T}$ he role of the local renin-angiotensin system (RAS) has been extensively studied in the progression of kidney disease. Previous research has indicated that local tissue production of angiotensin II (Ang II), which functions in an intracrine, autocrine and paracrine manner, is important in the progression of kidney disease. Clinical and animal studies have shown that treatment with angiotensin-converting enzyme inhibitors and Ang II type 1 receptor blockers reduces the progression of diabetic nephropathy, thereby resulting in effective amelioration of proteinuria and glomerular damage. However, these benefits cannot be fully explained only by the hemodynamic effects of the system causing a reduction in blood pressure. $^{1,2}$

In addition to the well-characterized systemic RAS, the presence of a local intrarenal RAS has now been generally accepted. The mRNA and functional proteins of the RAS, including angiotensinogen (AGT), renin, prorenin receptor, ${ }^{3}$ angiotensin I-converting enzyme and Ang II receptors (AT-1 and AT-2 subtypes), are expressed in rat mesangial cells, ${ }^{4,5}$ mouse and rat immortalized renal proximal tubular cells $s^{6,7}$ and rat collecting duct cells ${ }^{8,9}$ (Table 1).

Vidotti et al. ${ }^{4}$ described a significant increase in Ang II generation in mesangial cells exposed to a high glucose concentration, suggesting that the mechanisms responsible for this enhancement primarily include an increase in intracellular renin activity paralleled by an increase in AGT gene expression. These increases indicate the availability of the substrate to renin. Interestingly, the increased expression of intrarenal AGT has been shown to be directly involved in disease

Professor DE Casarini is at the Department of Medicine, Nephrology Division, Federal University of Sao Paulo, Rua Botucatu 740, São Paulo 04023040, Brazil.

E-mail: dulce@nefro.epm.br progression in several animal models of renal injury. ${ }^{10,11}$

Brezniceanu et al. ${ }^{12}$ demonstrated that tumor growth factor- $\beta 1$ stimulates Ang gene expression in rat kidney proximal tubular cells and that its action is mediated, at least in part, by reactive oxygen species (ROS) generation, p38 MAPK activation and p53 expression. These results suggest that Ang II and tumor growth factor- $\beta 1$ form a positive feedback loop to enhance their respective gene expression, leading to renal injury.

Although the signal transduction pathways involved in AGT expression have been described by several authors, the mechanism has not been completely elucidated. ${ }^{13,14}$

In this issue of Hypertension Research, Ohashi et al. ${ }^{15}$ demonstrated that the levels of glomerular AGT expression in Zucker diabetic fatty (ZDF) obese rats were higher than the levels in ZDF lean rats. In addition, they reported increased levels of immunoreactivity for 4-hydroxy-2-nonenal, urinary excretion of 8 -isoprostane and markers of ROS in the ZDF obese animals. They also focused on the signal transduction pathway for glomerular AGT expression. $\quad \mathrm{H}_{2} \mathrm{O}_{2}$ induced an increase in AGT expression in a dose-dependent and time-dependent manner, and the $\mathrm{H}_{2} \mathrm{O}_{2}$-induced upregulation of AGT was suppressed by catalase. Moreover, the $\mathrm{H}_{2} \mathrm{O}_{2}$-induced upregulation of AGT was inhibited by a mitogen-activated protein kinase (MAPK), a kinase inhibitor (MEK) and a c-Jun amino-terminal kinase (JNK) inhibitor, but was not inhibited by a p38 MAPK inhibitor.

Two aspects of their results were particularly intriguing. First, they offered further evidence for the pathological role of an activated AGT in mesangial cells found in ZDF rats with diabetic nephropathy. Second, their data demonstrated increased AGT expression in mesangial cells mediated by $\mathrm{H}_{2} \mathrm{O}_{2}$ with activation of extracellular-regulated kinase (ERK)/JNK pathways, but not p38 MAPK pathways. This result provides a new mechanism for the activation of intrarenal RAS in diabetic nephropathy. The increase of AGT could result in high levels of Ang II in these cells, which may result in intracrine actions involved in the well-known effects of diabetic nephropathy, such as induction of gene expression (particularly genes involved in cell growth and metabolism), synthesis of extracellular matrix components, and manifestations that are typical of diabetic nephropathy.

\section{ARE THERE CLINICAL IMPLICATIONS FOR INCREASED INTRARENAL AGT?}

AGT is the only known substrate for renin, which is the rate-limiting enzyme of RAS. The results described by Ohashi et al., in addition to previous studies from Kobori's group that found elevated urinary AGT levels in patients with chronic kidney disease including patients with diabetes, confirm that urinary AGT levels can function as an

Table 1 RAS along the nephron

\begin{tabular}{llc}
\hline Nephron & Intrarenal RAS & References \\
\hline Mesangial cells & ACE, AGT, All, Ang 1-7, renin, renin pro-receptor, AT1 and AT2 & $3-5$ \\
Proximal tubule & ACE, AGT, All, Ang 1-7, renin, renin pro-receptor, AT1 & 6,7 \\
Distal tubule & AGT, All & 8 \\
Collecting duct & ACE, AGT, All, Ang 1-7, renin, renin pro-receptor, AT1 & 8,9 \\
\hline
\end{tabular}

Abbreviations: ACE, angiotensin I-converting enzyme; AGT, angiotensinogen; Ang II receptors; AT-1 and AT-2 subtypes; RAS, rennin-angiotensin system. 
early biomarker for determining the status of the intrarenal RAS.

These results strengthen the role of tissue RAS acting in an autocrine, paracrine or intracrine manner in local kidney control.

1 Bader M, Peters J, Baltatu O, Muller DN, Luft FC, Ganten D. Tissue renin-angiotensin systems: new insights from experimental animal models in hypertension research. J Mol Med 2001; 79: 76-102.

2 Andersen $\mathrm{NH}$, Mogensen CE. Angiotensin converting enzyme inhibitors and angiotensin II receptor blockers: evidence for and against the combination in the treatment of hypertension and proteinuria. Curr Hypertens Rep 2002; 4: 394-402.

3 Nguyen G. The (pro)renin receptor in health and disease. Ann Med 2010; 42: 13-18.

4 Vidotti DB, Casarini DE, Cristovam PC, Leite CA, Schor $\mathrm{N}$, Boim MA. High glucose concentration stimulates intracellular renin activity and angiotensin II generation in rat mesangial cells. Am J Physiol Renal Physiol 2004; 286: F1039-F1045.
5 Andrade MCC, Di Marco GS, Teixeira VPC, Mortara RA Sabatini RA, Pesquero JB, Boim MA, Carmona AK, Schor N, Casarini DE. Expression and localization of $\mathrm{N}$-domain ANG I-converting enzymes in mesangial cells in culture from spontaneously hypertensive rats. $A m ~ J$ Physiol Renal Physiol 2006; 290: F364-F375.

6 Ingelfinger JR, Zuo WM, Fon EA, Ellison KE, Dzau VJ. In situ hybridization evidence for angiotensinogen messenger RNA in the rat proximal tubule. An hypothesis for the intrarenal renin angiotensin system. J Clin Invest 1990; 85: 417-423.

7 Loghman-Adham M, Rohrwasser A, Helin C, Zhang S, Terreros D, Inoue I, Lalouel JM. A conditionally immortalized cell line from murine proximal tubule. Kidney Int 1997; 52: 229-239.

8 Prieto-Carrasquero MC, Botros FT, Pagan J, Kobori $\mathrm{H}$, Seth DM, Casarini DE, Navar LG. Collecting duct renin is upregulated in both kidneys of 2-Kidney, 1-Clip goldblatt hypertensive rats. Hypertension 2008; 51: 1590-1596.

9 Quinto BMR, Andrade MCC, Ronchi FA, Santos EL, Correa SAA, Shimuta SI, Pesquero JB, Mortara RA, Casarini DE. Expression of angiotensin I-converting enzymes and bradykinin B2 receptors in mouse inner medullary-collecting duct cells. Int Immunopharmacol 2008; 8: 254-260.

10 Singh R, Singh AK, Leehey DJ. A novel mechanism for angiotensin II formation in streptozotocin-diabetic rat glomeruli. Am J Physiol Renal Physiol 2005; 288 : F1183-F1190.

11 Kobori H, Ozawa Y, Suzaki Y, Nishiyama A. Enhanced intrarenal angiotensinogen contributes to early renal injury in spontaneously hypertensive rats. J Am Soc Nephrol 2005; 16: 2073-2080.

12 Brezniceanu ML, Wei CC, Zhang SL, Hsieh TJ, Guo DF, Hebert MJ, Ingelfinger JR, Filep JG, Chan JS. Transforming growth factor-beta 1 stimulates angiotensinogen gene expression in kidney proximal tubular cells. Kidney Int 2006; 69: 1977-1985.

13 Satou R, Gonzalez-Villalobos RA, Miyata K, Ohashi N, Katsurada A, Navar LG, Kobori H. Costimulation with angiotensin II and interleukin 6 augments angiotensinogen expression in cultured human renal proximal tubular cells. Am J Physiol Renal Physiol 2008; 295 : F283-F289.

14 Hsieh TJ, Zhang SL, Filep JG, Tang SS, Ingelfinger JR, Chan JS. High glucose stimulates angiotensinogen gene expression via reactive oxygen species generation in rat kidney proximal tubular cells. Endocrinology 2002; 143: 2975-2985.

15 Ohashi N, Urushihara M, Satou R, Kobori H. Glomerular angiotensinogen is induced in mesangial cells in diabetic rats via reactive oxygen speciesERK/JNK pathways. Hypertens Res 2010; 33: 1174-1181 